\title{
The way out of Basic Income's utopia trap. Making sense of the basic income debate
}

\author{
Georg Vobruba (vobruba@rz.uni-leipzig.de) \\ Universität Leipzig, Germany
}

The considerable public attention given internationally to the idea of a guaranteed basic income stands in stark contrast to the chances of its implementation. The main cause is that the discussion avoids problems that are difficult to solve and focuses instead on normative justifications for a basic income. How to get out of this 'utopia trap'? Making sense of the basic income debate requires combining analyses of the problems and perspectives of existing welfare states with a strategy of reform steps towards the implementation of basic income.

Keywords: Basic income, Experiments, Digitisation

\section{Why is it important?}

In the last two decades, the demand for a basic income has become a public issue almost worldwide. Nonetheless: The presence of the demand stands in stark contrast to the chances of its implementation. In view of the decades of broad discussion about a basic income and the many ways in which it can be connected, it is very surprising that the idea of a basic income is still far from being put into practice. What is the reason for this? My thesis is that the discussion is far too little concerned with strategic issues. This deficit has led the basic income idea into a utopia trap. For this reason, I do not want to enumerate the possible advantages and problems of a basic income here, but rather draw attention to some strategic deficits in the discussion and suggest ways of overcoming them. The discussion on a guaranteed basic income is important and instructive. There are two reasons for this, an atmospheric one for everyday politics and a socio-political one for fundamental principles.

The political-climatic reason: The political discussions, as far as they go beyond the politics of the day, have been going on for quite some time in rather narrow, pragmatic tracks. "Be realistic, demand the impossible" is completely out of fashion. As far as I can see, this is true in general, but it is particularly true of social policy. Not only is there no shortage of diagnoses of increasing inequality, disenfranchisement, social relegation and the fear of it. They are even peculiarly popular (Picketty, 2014). But debates on redistribution, social security and social policy have been conducted mainly defensively for decades. In view of this basic mood, the discussion of a basic income seems to have an element of a political culture of 'cheerful demand' against the dominant Sachzwang-construction of politics and economics. This is by no means about political folklore. The demand for a basic income stands against a basic political and cultural mood that has serious institutional consequences. The dominant economic mainstream sees social security as little more than a hindrance to the economy, at best a necessary evil. This manifests a loss of socio-political 
expertise, which threatens to become irreversible through scientific policy decisions. The social science infrastructure for social policy research is being thinned out, the number of social policy chairs is being reduced, and research institutes are weakening their social policy profile. The result is that the topic of social policy is losing ground in academic and public debates. The pool of socio-political expertise that can be drawn on politically and administratively is shrinking (Kaufmann et al., 2016).

The fundamental socio-political reason: The basic income discussion is excellently suited for discussing fundamental socio-political problems (see Van Parijs, 1991; Blaschke, 2008). Questions of human dignity. According to which criteria does it determine itself? And who determines the criteria? Questions about the prerequisites and content of democracy, questions about conditions of social integration and recognition, questions about the meaning of work, questions about the legitimate domain of politics. I am by no means claiming that the introduction of a basic income would provide a convincing answer to all these questions. However, I believe that the demand for a basic income acts as a kind of socio-political litmus test. The reactions to the demand reveal positions on the fundamental issues mentioned. We learn a great deal about those in favour, but also about those critical or even denunciatory of the idea of a basic income.

\section{2. "Unconditional"?}

An unconditional basic income for all is hardly conceivable. I therefore consider the term "guaranteed basic income" (Opielka \& Vobruba, 1986) to be more precise. In fact, the term 'unconditional' helps to ignore questions that are difficult to answer and disturb idyllic basic income ideas. But this aid is deceptive. Two limitations of 'unconditionality' are inevitable, they should be discussed socio-scientifically and politically offensively. 1) The circle of eligible persons is always spatially limited. The demand 'basic income for all' does not solve the problem, but conceals it. Formulating exclusions is unpleasant. This is precisely what is meant by disturbances of idyllic basic income ideas. 2) An age limit must be defined for the receipt of a basic income. To demand a basic income "for all" (Vanderborght \& Van Parijs, 2005) is therefore delusory.

First limitation: The spatial limitation of the circle of entitled persons is generally taken into account, but not explicitly made and specified. An example: The (Mini-)party Bündnis Grundeinkommen ("alliance for a basic income" - my translation) in the Federal Republic of Germany defines the basic income in its programme (2016) as an individual legal entitlement "without means test and without coercion to work or other consideration" (my translation). It is a cash benefit which "a political community unconditionally grants to each of its members". Throughout the programme, there is no word on this limitation: who belongs to the "political community"? And above all: who does not belong to it? And what is to be understood by a "political community" at all? This is a lack of definition which becomes a strategic problem when it comes to the serious realisation of a basic income. The demand for a worldwide basic income is a logical but illusionary consequence of this.

Second limitation: At what age should one be entitled to receive the guaranteed basic income? This question is closely related to the question of the effects of a basic income on work motivation. Nobody can say with sufficient certainty what influence a basic income would have on the biographical work orientation in young people. After all, it would be conceivable that it would disturb the orientation towards education and work. And on top of that, this influence does not only arise at the time of payment, but already through the prospect of the basic income, i.e. much earlier. All the good arguments that people with a basic income would continue to work anyway draw their plausibility from an already completed work socialisation. "What would you do if you were to receive a thousand euros unconditionally every month?" Such questions, directed at middle-aged people, do not open up much, for all answers are from people who would be the first generation in a 
'basic income era'. However, the decisive question for the young generation may not be: will there be enough people willing to take on unpleasant but unavoidable jobs? This problem can probably be solved with sufficiently high wages. The decisive open question is rather: How many will manage to find their way into a "vita active" at all (Arendt, 2002)? Well-meaning references to human innate creativity are not enough.

\section{Effects on supply}

This leads to the great uncertainty regarding the question of how a basic income would affect the supply of labour. This problem has long been the subject of intense debate. Hopeful expectations of unleashed creativity stand against gloomy forecasts of a general flight from work. The shrugging statement that there are different 'images of people' is unsatisfactory. It is largely undisputed in the discussion that, assuming a sufficient level, a basic income would have a modifying effect on the supply of labour. The thesis that a basic income would weaken (wage) work orientation and reduce the supply of labour on the labour market can be found in two variants. Reducing the supply of labour is seen as either unproblematic (A) or desirable (B). A. The reduction of the labour supply appears to be unproblematic against the background of the view that the socially relevant part of the work is carried out away from the labour market anyway. This argument was previously linked to very optimistic assessments of the potential of the alternative economy, later to the high estimation of voluntary work, housework and care work, etc. An empirical underpinning of this thesis is difficult. In fact, it turned out that the potentials of the alternative economy were far overestimated, especially in the early 1980s. Complementarities between paid and unpaid work must also be assumed rather than substitutability. B. Reducing the supply of labour appears desirable against the background of the conviction that demand for labour is declining anyway. This opens up the debate on basic incomes to questions about the long-term development of the labour market on two sides: the supply side and the demand side. Empirically sound answers to these questions are complicated. I will have to content myself here with approximations

\section{Approximations}

Any meaningful discussion of the quantitative effects of a basic income on labour supply should begin with an admission that little is known about the effects of a basic income on work orientation. An additional difficulty results from the interactions between labour market effects and the costs of a basic income, which from a dynamic point of view is difficult to control. Overall, there are only a few research results on these questions that directly target the relationship between basic income and the labour market. There are some model simulations and the results of several basic income experiments. Both are of limited informative value (I will come back to the problem of the experiments briefly). Nevertheless, empirical research results are available that can be used as approximations to answers to the question of the labour market effects of a basic income.

A basic income causes a slight decline in the supply of labour overall, and a somewhat stronger decline in the lower income bracket. Here, labour becomes more expensive because the basic income acts as a 'reservation wage' for some of the providers of labour. Together with the reduced supply in the lower income bracket, this leads to wage increases. However, some of this withdrawal effect will be reversed in the longer term because the demand for previously low-paid labour will decline, as sector-specific automation, the transfer of labour to customers, etc., will lead to savings of paid labour. However, experience with the introduction of a minimum wage in Germany suggests that these effects would probably not be very pronounced. Accordingly, warnings from economists against a basic income should be put into perspective. The fact that the negative effects on employment resulting from the minimum wage in Germany (introduced in 2015) 
have largely failed to materialise (Bellmann et al., 2016) has not yet been analysed in social science as a collective misforecast of the economist profession. But it has also been overlooked so far that the introduction of the minimum wage can serve as a quasi experiment for some effects of a basic income in question.

For a considerable part of the labour force, non-monetary motives for their supply behaviour on the labour market obviously also have an effect. Empirical evidence of this can be gained from the empiricism of the 'top-ups' (Aufstocker). Topping up the low earned income means supplementing it by a social transfer up to the income level they would achieve if they only received the social transfer. Depending on the concrete design of the rules for crediting earned income to social transfers for non-employees who are able to work, such top-ups hardly have any material advantages from taking up paid work. Although limited by administrative controls of the employment offices/agencies, this group would have the alternative of living entirely on social transfers. Thus, top-ups take up work for their own sake, be it because an activity is regarded as particularly meaningful, be it so that "the ceiling does not fall on your head", be it to escape the "unemployment trap" (Gebauer et al., 2002; Gebauer \& Vobruba, 2003). Otherwise, there would be fewer transitions between social assistance and the labour market (Leisering \& Leibfried, 1999). That means: Taking up work despite a socio-political incentive structure, which makes it financially unattractive to take up low-paid work due to hight withdrawal rates of labour income on social transfers (Vobruba, 1986/2019, 349), therefore tempts one to remain in the social transfer system and thus deprive oneself of later opportunities for advancement and income (hence the unemployment trap). Two arguments can be developed regarding these results. First, they lead to the conclusion that the Hartz IV reform addressed a sham problem: The problem that the acceptance of dependent employment is prevented by socio-political false incentives did not exist, or not to the presumed extent. Transitions from social transfer to work take place much more frequently and for different reasons than economic common sense and prejudices against the unemployed assume. In other words, institutional incentives do not automatically translate into appropriate action (Vobruba, 2004). At the same time, the reform increased disenchantment with democracy, protest voting and polarisation tendencies in society (Butterwegge, 2015; Fervers, 2018). This results in an extremely unfavorable balance. The Hartz IV reform largely dealt with a pseudo problem, but it does cause high real political costs (Fehr \& Vobruba, 2011). Secondly, such empirical results on supply behaviour cannot be converted into the labour market effects of a basic income. However, it is possible to gain insights into mechanisms that would work in the direction of more moderate labour market effects from the introduction of a basic income.

It is unlikely that a basic income will lead to additional labour supply, i.e. counteract the withdrawal effect of a basic income. Some fear that the supply of labour in the low-wage sector would increase as a result of a basic income, because employers and employees could agree on lower (hourly) wages through a basic income. However, this assumption is only plausible in the case of jobs that are primarily performed for their own sake and not for income reasons. As has already been said, this presupposes specific, intrinsic work motives. In such cases, a basic income does not act as a wage floor, but as a wage subsidy. This is possible when taking up work for non-monetary reasons. On the other hand, the concern that a basic income is a means of pressure to involuntarily take up low-paid work is incomprehensible - at least if one assumes a sufficient level of the basic income, which therefore acts in the sense of a 'reservation wage'. On the premise of a basic income, individually reduced working hours and constant or increased hourly wages are more likely. 


\section{Experiments}

One can counter all this by saying that these are just approximations. That's true, but this argument doesn't work: I'm not here to collect arguments for or against a basic income. My intention is to point out open questions, to articulate doubts that are in the air anyway, to make them explicit and thus possible to clarify. This presupposes taking note of the state of research and using it, and subsequently asking further questions. Confessions are of no use.

Overall, little is known about the effects of a guaranteed basic income on the labour supply. Basic income experiments are currently in vogue (McFarland, 2017), but they are of limited help. Experiments are always designed for a definite period, and they always cover selected groups of the population only. This must be the case (otherwise they would not be experiments, but the introduction of a basic income), but their significance is considerably limited, particularly with regard to the supply of labour. First, reactions depend on whether one can expect a basic income for a fixed period of time (experiment) or forever (introduction). Who will seriously think about quitting a job when they know that the basic income will soon be gone? This could explain why basic income experiments tend to reduce labour supply less than expected (Burtless, 1988; Widerquist, 2005) and, above all, to undertake additional activities that can be seen as an investment for the time afterwards (further training; curing a protracted illness). Secondly, a basic income will have very different effects, depending on whether everyone in a (nationally constituted) society receives a basic income or only one test group. Under no circumstances can one tell from a test group whether a basic income triggers a fundamental cultural change. And the effects are most likely to be distorted once again, as the test persons compete with all the others on the labour market again after the end of the test phase. All in all: You can compare test groups equipped with different versions of a basic income with each other, but you cannot extrapolate from the test results to society. There is no way around it: If you want to know whether and how a basic income changes society, you have to introduce it. This is a difficult obstacle to overcome.

\section{Digitisation}

Digitisation brings with it the fear and hope of a sharp reduction in the demand for labour. Digitisation is relatively new, but the idea that society is losing its jobs as a result of technological progress, or that technology frees society from work, is an ancient one. The utopian novels of the 19th century are full of this hope. The idea of immense productivity advances also played a major role in the basic income discussion of the 1980s. The appearance of the first self-controlling engines were expected to lead to leaps in overall economic productivity and irreversible job losses. Nothing of the sort happened. Well, it could be that a qualitatively completely new technological push is actually taking place at the moment. But this would first have to be demonstrated. The fact that in the economically most advanced societies the increases in overall economic productivity decrease in the long term speaks against this. To the extent that the discussion about job losses due to digitisation is based on empirical data at all, one finds a characteristic pattern: the prospect of drastic losses is made plausible by "partial analysis", i.e. usually on the basis of examples. Analyses, on the other hand, which set off the gains and losses of jobs through digitisation for the entire economy (here: the Federal Republic of Germany) against each other, arrive at very moderate results (Walwei, 2016; Eichhorst et al., 2016). This suggests two conclusions. First: Digitisation leads to job losses and to new jobs. It generates less productivityrelated unemployment than problems of adaptation to new qualification requirements. Second: The discourse constellation today resembles the debate in the 1980s about productivity increases and technologically induced unemployment (Gorz, 1985; Kollektiv Charles Fourier, 1985). The then still relatively new experience of unemployment, which 
hardly diminished in economic upswings, became the thesis of the work society, which extrapolates 'the work runs out', which developed considerable suggestive power. The fact that the forecasts made at the time were not accurate should motivate caution: All those who see immense economic productivity boosts as a result of digitisation should first show what exactly is fundamentally different about the situation today than it was at the time of the diagnosis of a technologically induced "end of work" (Dahrendorf, 1983; Rifkin, 1995).

Politically and strategically, this means that the scope for distribution is narrower, and the distribution conflicts that any strategy to enforce a basic income must reckon with will be much more intense than depicted in the hopeful digitisation scenario. The idea that digitisation provides both the problem (unemployment) and the means to solve it ("social wealth" used as a basic income for all) is deceptive. Accordingly, financing proposals aimed at taxing any features of machines are misleading. Taxes can only be levied on persons who earn income from the use of machines, not on machines themselves. All proposals on "machine taxes" are based on the confusion between the tax base and the taxpayer. This means, however, that one has to reckon with their distribution interests, alternative strategies and resistance. The discussion on basic incomes must therefore be underpinned by conflict theory, relate to positions of interest pro and contra, and shift its focus from normative arguments to questions of power and enforcement (Greven, 1986).

\section{Ways out}

The sudden demand for a guaranteed basic income has something very relieving about it. One moves in the ideal world of the normative: first a bad social actual condition is diagnosed, then a basic income is set against it as a target. A basic income is "objectively" necessary, one only has to seize the historical opportunity. There are many good reasons for a basic income, it is therefore a requirement of reason to introduce it. Accordingly some see it as "a black-red-green reform proposal". Is it? Caution is advised when arguing in favour of a basic income without interest. This does not mean that intersections of common interests are excluded. But the concerns must be taken very seriously (Glotz, 1986; Butterwegge, 2014; Bothfeld, 2018) that a basic income will be used as a cover for the implementation of social policy reduction plans. It is therefore absolutely essential not to dismantle existing social policy in the first place and then envisage a basic income. This alone determines every conceivable introduction of a basic income as a conflict-laden, incremental strategy.

But how do you get from here to there politically? A brief thought might help. If a basic income can only be introduced with a big leap, then it cannot be introduced at all. That is the utopia trap. In order to avoid it, one has to consider the gradual realisation of the basic income. There are serveral important socio-political goals which can be achieved through a basic income, but not just through a basic income (Leibfried, 1986; Vobruba, 2019). This also means that these goals can be achieved not only through a basic income, but through a basic income among other instruments. Effective poverty reduction, for example, does not necessarily require a basic income, but a basic income can combat poverty. Reforms can therefore be seen as independent political projects, but they can also be seen as steps towards a guaranteed basic income. This resolves the confrontation between various proposals for a basic income and basic security and the demand for a basic income. So what is necessary?

1. What is needed are reform steps that bring immediate improvements and for which there are political allies beyond the basic income scene. 2. Under no circumstances should one run the risk of getting stuck in a situation where the steps towards introducing a basic income are worse than the current status quo. Every reform torso must therefore be acceptable. 3 . This has the advantage that the reform steps towards a basic income already 
show what they are ultimately intended to achieve. Thus the ideological and socio-political ambiguities of different proposals must be resolved by institutional design in practice - not only by confession with formula like 'emancipatory basic income'.

The question of gradual realisation has long been a secondary theme in the debate on a basic income (Opielka, 1986). I have the impression that all those who base their sceptical position essentially on the concern that, in the slipstream of the introduction of a basic income, the achievements of the welfare state would be recklessly relinquished, should deal with the many proposals for gradualist enforcement strategies. Conversely, advocates of such strategies should focus more on the actual development of social policy at national, European and global level; and above all on the fact that numerous recent social policy reforms in Europe tend to lead even further away from a basic income as a general orientation. A long time ago this was different and provided an opportunity to see a basic security logic slowly asserting itself in socio-political reforms. But at least since the late eighties there was a socio-political convergence trend in Europe towards a reduction in the level of social benefits while at the same time strengthening the focus on wage labour -i.e. in the opposite direction to a basic income (Fehmel, 2013; Vobruba, 1997). The trend towards privatisation and marketisation of social security also has an effect in the sense of a closer interdependence between earned income status and security benefits. It is therefore a matter of analysing the condition factors (power relations, institutional dynamics, etc.) of actual socio-political development and of analysing the tension between these tendencies and plans for a guaranteed basic income. Political action cannot replace analysis, but must build on it. In this way, strategies can be developed that lead the basic income out of the utopia trap.

\section{References}

Arendt, Hannah (2002): Vita activa oder vom tätigen Leben. München, Zürich: Piper.

Bellmann, Lutz et al., Folgen des Mindestlohns in Deutschland: Betriebe reagieren nur selten mit Entlassungen. IAB Kurzbericht 18/2016. Retrieved from http://doku.iab.de/kurzber/2016/kb1816.pdf

Blaschke, Ronald (2008): Bedingungsloses Grundeinkommen versus Grundsicherung. rls Standpunkte 15.

Bothfeld, Silke (2018): Das bedingungslose Grundeinkommen zwischen Utopie und sozialstaatlicher Wirklichkeit. Leviathan, 46(1), 81-108.

Bündnis Grundeinkommen (2016): Programm. Retrieved from: https://www.buendnisgrundeinkommen.de/ueber-uns/programm/

Burtless, Gary (1988): The Work Response to a Guaranteed Income: A Survey of Experimental Evidence. Washington, D.C.: Brookings Institution.

Butterwegge, Christoph (2014): Krise und Zukunft des Sozialstaates. 5. Aufl. Wiesbaden: Springer VS.

Butterwegge, Christoph (2015): Hartz IV und die Folgen. Auf dem Weg in eine andere Republik? Weinheim, Basel: Beltz Juventa. 
Dahrendorf, Ralf (1983): Wenn der Arbeitsgesellschaft die Arbeit ausgeht. In: Joachim Matthes (Ed.), Krise der Arbeitsgesellschaft? Verhandlungen des 21. Deutschen Soziologentages in Bamberg 1982. Frankfurt a. M., New York: Campus, 25-37.

Drange, Ida \&Jakobsson, Niklas (2018): Incentive effects of cash benefit among young people. A natural experiment from Norway. Journal of Social Policy, 48, 1-19.

Eichhorst, Werner et al. (2016): Digitalisierung und Arbeitsmarkt: Aktuelle Entwicklungen und sozialpolitische Herausforderungen. Zeitschrift für Sozialreform, 62(4), 383-409.

Fehmel, Thilo (2013): Sicherungsbewahrung. Europas sozialpolitische Zukunft. Weinheim, Basel: Beltz Juventa.

Fehr, Sonja \& Vobruba, Georg (2011): Die Arbeitslosigkeitsfalle vor und nach der HartzIV-Reform. WSI Mitteilungen 5/2011, 211-217. Retrieved from https://www.boeckler.de/wsimit_2011_05_fehr.pdf

Fervers, Lukas (2018): Economic miracle, political disaster? Political consequences of Hartz IV. Journal of European Social Policy, 29(3). Retrieved from http://journals.sagepub.com/doi/abs/10.1177/0958928718774259

Gebauer, Ronald, Petschauer, Hanna \& Vobruba, Georg (2002): Wer sitzt in der Armutsfalle? Selbstbehauptung zwischen Sozialhilfe und Arbeitsmarkt. Berlin: Sigma.

Gebauer, Ronald \& Vobruba, Georg (2003): The open unemployment trap. life at the intersection of labour market and welfare state. The case of Germany. Journal of Social Policy, 32. 571-587.

Glotz, Peter (1986): Freiwillige Arbeitslosigkeit? Zur neueren Diskussion um das „garantierte Grundeinkommen“. In: Opielka, Michael \& Vobruba, Georg (Eds.): Das garantierte Grundeinkommen. Entwicklung und Perspektiven einer Forderung. Frankfurt a. M.: Fischer, 135-148.

Gorz, André (1985): Paths to paradise. On the liberalization from work. London: Pluto Press.

Gorz, André (1986): Garantierte Grundversorgung aus rechter und linker Sicht. In: Opielka, Michael \& Vobruba, Georg (Eds.): Das garantierte Grundeinkommen. Entwicklung und Perspektiven einer Forderung. Frankfurt a. M.: Fischer, 53-62.

Greven, Michael Th. (1986): Von der Sozialleistung zum Bürgergehalt. Die Entprivatisierung des gesellschaftlichen Reichtums. In: Opielka, Michael \& Vobruba, Georg (Eds.): Das garantierte Grundeinkommen. Entwicklung und Perspektiven einer Forderung. Frankfurt a. M.: Fischer, 63-69.

Kaufmann, Franz-Xaver, Leibfried, Stephan, Hockerts, Hans Günter \& Zürn, Michael (2016): Standpunkt: Zur Entwicklung von Forschung und Lehre zur Sozialpolitik an Universitäten in der Bundesrepublik Deutschland. Ein wissenschaftlicher Denkanstoß aus der Akademie. Sozialer Fortschritt, 65, 119-125. Retrieved from https://ejournals.dunckerhumblot.de/doi/abs/10.3790/sfo.65.5.119 
Kollektiv Charles Fourier (1985): Das allgemeine Grundeinkommen. In: Opielka, Michael (Ed.): Die ökosoziale Frage. Frankfurt a. M.: Fischer, 235-242.

Leibfried, Stephan (1986): Bedarfsprinzip und Krise sozialer Grundsicherung. In: Opielka, Michael \& Vobruba, Georg (Eds.): Das garantierte Grundeinkommen. Frankfurt a. M.: Fischer.

Leisering, Lutz \& Leibfried, Stephan (1999): Time and poverty in western welfare states. Cambridge: Cambridge University Press.

Matthes, Joachim (Ed.) (1983): Krise der Arbeitsgesellschaft? Verhandlungen des 21. Deutschen Soziologentages in Bamberg 1982. Frankfurt a. M., New York: Campus.

McFarland, Kate (2017): Existing and upcoming Bl-related experiments. Retrieved from https://basicincome.org/news/2017/10/overview-of-current-basic-income-related-experiments-october-2017/

Offe, Claus (2009): Das bedingungslose Grundeinkommen als Antwort auf die Krise von Arbeitsmarkt und Sozialstaat. In: Neuendorff, Hartmut, Peter, Gerd \& Wolf, Frieder O. (Eds.): Arbeit und Freiheit im Widerspruch? Bedingungslosen Grundeinkommen - ein Modell im Meinungsstreit. Hamburg: VSA, 20-43.

Opielka, Michael (1986): Perspektiven von Arbeit und Einkommen in der Wohlfahrtsgesellschaft. Aus Politik und Zeitgeschichte B36/1986, 37-55.

Opielka, Michael \& Vobruba, Georg (Eds.) (1986): Das garantierte Grundeinkommen. Entwicklung und Perspektiven einer Forderung. Frankfurt a. M.: Fischer Tb.

Piketty, Thomas (2014): Capital in the twenty-first century. Cambridge, Mass., London: Harvard University Press.

Rifkin, Jeremy (1995): The end of work. New York: Putnam.

Standing, Guy (2014): The precariat. The new dangerous class. London etc.: Bloomsbury.

Van Parijs, Philippe (1991): Why surfer should be fed: The liberal case for an unconditional basic income. Philosophy \& Public Affairs, 20(2), 101-131.

Vanderborght, Yannick \& Van Parijs, Philippe (2005): Ein Grundeinkommen für alle? Frankfurt a. M., New York: Campus.

Vobruba, Georg (1997): Social Policy for Europe. In: Beck, Wolfgang, van der Maesen, Laurent \& Walker, Alan (Eds.): The Social Quality of Europe. The Hague, London, Boston: Kluwer Law International, 105-120.

Vobruba, Georg (2004): Incentive and action. Work and income decisions at the intersection of the labour market and the welfare state. In: Littlewood, Paul, Glorieux, Ignace, \& Jönsson, Ingrid (Eds.): The Future of Work in Europe. Aldershot: Ashgate, 65-81.

Vobruba, Georg (1986/2019): Die Entflechtung von Arbeiten und Essen. In: Philip Kovce \& Birger Priddat (Eds.): Bedingungsloses Grundeinkommen. Berlin: Suhrkamp, 338-355. 
Vobruba, Georg (2019): Entkoppelung von Arbeit und Einkommen. Das Grundeinkommen in der Arbeitsgesellschaft. (3rd ed.) Wiesbaden: Springer VS.

Walwei, Ulrich (2016): Konsequenzen der Digitalisierung für strukturelle Arbeitsmarktprobleme: Chancen und Risiken. In: Zeitschrift für Sozialreform, 62(4), 357-382.

Widerquist, Karl (2005): A Failure to Communicate: What (if anything) can we learn from the negative income tax experiments? The Journal of Socio-Economics, 34(1), 49-81. 